\title{
ARE DEMOCRATISING COUNTRIES REWARDED WITH HIGHER LEVELS OF FOREIGN AID?*
}

\author{
Balázs SZENT-IVÁNYI \\ (Received: 28 January 2014; revision received: 23 May 2014; \\ accepted:11 January 2015)
}

The paper examines how flows of foreign aid have reacted to events of democratisation in developing countries. Using a panel dataset of 136 aid-receiving countries between 1980 and 2009, aid allocation regressions reveal that Western donors in general have tended to react to visible, major democratic transitions by increasing aid to the partner country, but no significant increases can be identified in the case of countries introducing smaller democratic reforms. The increases in aid flows are not sustained over time, implying that donors do not provide long-term support to nascent democracies. Also, democratisations in Sub-Saharan Africa do not seem to have been rewarded with higher levels of aid.

Keywords: foreign aid, aid allocation, democratisation

JEL classification indices: F35, F59

* The author wishes to thank Gábor Rúzsa and the two anonymous referees for their valuable comments. Any remaining errors are those of the author. The research was supported in the framework of the project TÁMOP 4.2.4. A/2-11-1-2012-0001 "National Excellence Program - Elaborating and operating an inland student and researcher personal support system" and co-financed by the European Social Fund.

Balázs Szent-Iványi, Lecturer at the School of Languages and Social Sciences, Aston University, Birmingham, UK, and Associate Professor at the Department of World Economy, Corvinus University of Budapest, Hungary. E-mail: b.szent-ivanyi@aston.ac.uk 


\section{INTRODUCTION}

Spreading the values of democracy, the respect for human rights and civil liberties as well as democratic governance became integral parts of the foreign strategies and external assistance policies of several large donors in the past decades. Donors increasingly used political conditionality attached to foreign aid and also put a large emphasis on supporting development projects that may directly impact and improve the quality of democracy. Political conditionality came in several forms, but most generally it involved providing positive incentives such as increased aid flows to countries undertaking democratic reforms.

Conditionality may be rather explicit in donor-recipient dialogues, but an implicit lesson is also identifiable in the external assistance policies of donors like the United States or the European Community. More democratic countries "deserve" more foreign aid, as aid may be more effective in a democratic setting, not to mention the moral dilemmas of supporting countries with non-democratic ruling elites. Nascent democracies may also be in need of external resources for building institutions and supporting state expenditure, as in the long run the new polities can only gain popular support by providing public services, as well as ensuring economic growth and the creation of jobs. The possibility of increased aid flows after an event of democratic change may induce local elites to undertake certain democratic reforms, but also provide rival elites an incentive to take over the state and introduce democracy. Thus, providing credible commitments on increasing aid flows to democratisers can contribute to the democracy promotion as well as the aid effectiveness agendas of many donors.

This paper addresses the question of just how credible such promises may be in the case of the OECD Development Assistance Committee (DAC) donors. Specifically, it examines how aid flows between 1980 and 2009 reacted to events of democratic change and whether countries introducing democratic reforms were actually "rewarded" with increased flows of aid. The policy relevance of this issue is rather straightforward: if donors were consistent in rewarding democratic change in the past, then any commitment to increase aid to new democracies in the future may seem more credible. The issue is especially relevant in the aftermath of the "Arab Spring" revolutions in North Africa and the Middle East. Will the consolidation of the emerging political systems in countries like Egypt, Tunisia or Libya be supported with increased levels of foreign aid?

Estimating aid allocation regressions on a panel dataset of 136 aid-receiving countries, the paper finds that on average Western (OECD) donors do seem to increase aid to countries which underwent a democratic transition. The paper thus adds to the literature on aid allocation by refining our understanding of how 
the level of democracy and democratic change influence the allocation decisions of donors, an issue which so far has only been marginally studied. An important methodological contribution of the paper is the disaggregation of democracy into differences between countries and changes within countries, which can provide a more refined understanding of donor behaviour.

The paper is organised as follows. The following section reviews the literature on aid allocation and the relationship between aid and democracy. Section 3 presents the methodology of the paper and the baseline regression model. Section 4 discusses the empirical results and tests them for robustness, while Section 5 concludes the paper.

\section{AID AND DEMOCRACY}

The relationship between the amount of foreign aid a country receives and the level of democracy within that country is one of two-way causality. The level of democracy can be a determinant of how much aid is allocated to a country, but aid can also have an impact on democracy in the recipient. This section starts by reviewing the first channel, i.e. the results and approaches of the literature on aid allocation in order to provide a broader theoretical framework for the econometric analysis, and then briefly assesses the literature on the impact of aid on democracy as well.

The quantitative aid allocation literature has long traditions, dating back to the works of McKinley - Little $(1977,1979)$ as well as Maizels - Nissanke (1984). Most studies group the determinant forces into three basic categories: donor interests, recipient needs, and, more recently, recipient merit (McGillivray 2003; Hoeffler - Outram 2011). The broad (and more or less consensual) conclusions of the literature can be summarised in three points:

1. Donor interest variables seem to be most important in explaining how much aid a country gets (Maizels - Nissanke 1984; Alesina - Dollar 2000).

2. In the decades after the Cold War, and especially in the years since the turn of millennium, recipient need and merit variables seem to have gained in relative importance, signalling a shift in the determinants of donor behaviour (Dollar - Levine 2006; Isopi - Mavrotas 2006; Claessens et al. 2009).

3. Donor allocation behaviour can be rather heterogeneous: there are clear differences between donors, with some being more selective or altruistic than others (Schraeder et al. 1998; Berthélemy - Tichit 2004; Dollar - Levine 2006; Berthélemy 2006). 
These three points aside, studies have identified a whole range of specific variables that impact donor aid allocation decisions. In the case of donor interests, political variables like colonial past, voting patterns in the United Nations General Assembly (Alesina - Dollar 2000), or the Cold War (Hoeffler - Outram 2011) have been shown to influence aid allocation. Economic donor self-interest also has explanatory power. Maizels - Nissanke (1984), for example, argued that the stock of foreign direct investment (FDI) in the recipient country is an important determinant, while Younas (2008) proved that developing countries which import more manufactured goods, mostly produced by high-income countries, also receive higher amounts of aid.

Recipient need variables have mostly taken the back seat, as opposed to donor interests. However, per capita income and infant mortality, signifying the financial and psychical needs of recipient countries, respectively, have been shown to be significant determinants of aid in some studies (Trumbull - Wall 1994; Wall 1995), with their importance growing in more recent ones (Bandyopadhyay Wall 2006; Dollar - Levine 2006).

Recipient merit is usually understood in terms of how the partner country performs either in economic terms or in some other issues such as institutional quality, democratic governance, the quality of democracy, or the respect for civil liberties and human rights. The underlying logic of recipient merit variables is that better performing countries should receive higher amounts of aid, a conclusion underpinned by advances in the aid effectiveness literature. In the early 2000 s, a large body of literature found evidence that aid is more effective in certain contexts than in others. These contexts mainly refer to "good" policies (Burnside - Dollar 2000), economic institutions (Collier - Dollar 2002; Burnside - Dollar 2004), but also to political systems. Boone (1996) argued that the impact of aid is greater in liberal political regimes, and Svensson (1999) echoed this conclusion with results showing that the long-run growth impact of aid is conditional on the respect for political rights and civil liberties in a country. Kosack (2003) concluded that the level of democracy in a country is the main determinant of how effective aid is in terms of alleviating poverty. While many of these results have been debated (Hansen - Tarp 2001; Easterly et al. 2004; Dovern -Nunnenkamp 2007), the conclusion emerges that if donor countries wish to maximise the impact of their resource transfers on growth or poverty reduction, one path could be to give more aid to those countries which have better quality policies as well as better economic and more democratic political institutions.

Measuring institutional quality, however, raises several questions, as indices measuring them are inherently subjective, and often not available in longer time series. Therefore, many papers have opted to proxy institutional or policy quality 
with an output side measure, most commonly the economic growth rate of the country (Berthélemy - Tichit 2004; Berthélemy 2006; Hoeffler - Outram 2011). Still, there are numerous examples of papers using indices that measure the quality of economic and political institutions directly, such as the World Bank's Country Policy and Institutional Assessment (CPIA) measure (Dollar - Levine 2006), or the Governance Matters indicators, also published by the World Bank (Bandyopadhyay - Wall 2006; Kaufmann et al. 2009). Alesina - Dollar (2000) use Freedom House's civil liberties and political rights indices and conclude that being more democratic has a significant, though rather small effect on aggregate aid flows from all donors. This result has been supported by Bandyopadhyay - Wall (2006), and also for many individual donors by Neumayer (2003a) and HoefflerOutram (2011), the latter using the Polity IV index instead of the Freedom House measure. It therefore seems that there is a significant and robust relationship between the level of democracy and the amount of aid a country gets.

There is, however, an important limitation in these results: it is not clear how much they are driven by cross-country differences in levels of democracy and how much by within country changes (i.e. events of democratic change). Alesina - Dollar (2000) have tried to address this question by simply comparing aid flows before and after an episode of democratisation for individual countries, but this approach clearly cannot tell us much on the ceteris paribus effect of an event of democratisation on aid flows. Therefore, the existing literature offers no clear answer on whether a democratising country can expect larger volumes of aggregate aid or not. This paper attempts to address this issue by disaggregating the measure of democracy into a level component and a change component (see the following section for more details) and providing ceteris paribus estimates of the effects of democratic changes on aid flows.

As mentioned, donors are not the same, and have different motivations for giving aid, different organisational structures, methods of delivery, etc. These differences are well documented in qualitative donor studies (Hoebink - Stokke 2005; Lancaster 2006). Some donors, like the UK, Sweden, the Netherlands, the European Commission, or the World Bank clearly place emphasis on supporting countries that have better quality institutions, higher level of respect for human rights, and "freer" political systems. Others, such as France, Japan or Belgium, have embraced political selectivity to a much smaller degree (Berthélemy 2006). There is evidence, however, that since the mid-1990s, many donors have become increasingly selective in their aid allocations, pointing to some degree of convergence among donor practices (Dollar - Levine 2006).

The literature on the reverse causation, i.e. the impact of aid on democracy is also rich, but inconclusive. In theory, aid can promote democracy through 
three channels (Knack 2004; Heckelman 2010): (1) through technical assistance aimed specifically at improving democratic practices, such as the electoral process, strengthening the judiciary or promoting civil society; (2) through political conditionality attached to aid; and (3) through improving education and increasing per capita income, both of which may be conducive to democracy. On the other hand, aid can harm democracy by eroding democratic governance (Knack 2001; Brautigam - Knack 2004; Busse - Gröning 2009) through channels like decreasing the need of local elites to raise revenues through taxation (Moss et al. 2006), inducing greater rent seeking among elites (Svensson 2000), overburdening state bureaucracies with related administrative requirements (Knack - Rahman 2007), or by releasing governments from binding revenue constraints (Janus 2009).

In the light of these conflicting theoretical considerations, it is not surprising that the empirical literature has yielded mixed results. Knack (2004) found no evidence that aid in general supports democratisation, while Djankov et al. (2008) reported an outright negative relationship. These findings were echoed by Kalyvitis - Vlachaki (2012), although they added that the negative relationship was moderated when aid flows were preceded by economic liberalisation. Dutta et al. (2013) argue that aid strengthens the existing political system it encounters regardless of its nature, thus aid has no power to promote democracy in dictatorships. Kono - Montinola (2009) show that foreign aid cumulated over time will promote the survival of autocratic leaders. The more optimistic papers conclude that aid may promote democracy, but only under certain circumstances. Wright (2009), for example, argues that dictators who have a large chance of remaining in power after democratisation tend to respond to aid by democratising, but otherwise aid will have no impact. Bermeo (2011) finds that aid provided by democratic donors increases the likelihood of democratic transition. This is good news, as most aid comes from democratic donors, although non-democracies like China are also increasingly important providers of aid (Tarrósy 2012). Kangoye (2011) concludes that aid can offset the negative effects terms of trade shocks may have on the quality of democracy, and Kalyvitis - Vlachaki (2011) as well as Dietrich - Wright (2013) find evidence that levels of democracy aid are positively correlated with the likelihood of democratic regime change.

Summing up this section, it seems that the causality running from democracy to aid allocation is stronger than the impact of aid on democracy, which is heavily contingent on recipient and donor context. The following section discusses the methodological issues and presents the dataset used. 


\section{METHODOLOGY}

\subsection{Model and data}

In order to examine how events of democratisation influence the amount of aid a country receives, the paper estimates a standard "donor interest, recipient need, recipient merit" model on a panel of aid-receiving countries for the years between 1980 and 2009. ${ }^{1}$ The observations are grouped into three-year averages in order to smooth out annual fluctuations. This is a reasonable compromise, as it still ensures a large number of observations. With 136 countries and 10 three-year periods, the dataset includes 1,360 maximum potential observations, but in practice, this number is limited by data availability. The panel is unbalanced.

The baseline panel equation is the following:

$$
\begin{gathered}
\ln \left(\text { ODAcap }_{\mathrm{it}}\right)=\beta_{0}+\beta_{1} \mathrm{dem}_{\mathrm{it}-1}+\beta_{2} \mathrm{dem}_{-1} \mathrm{lev}_{\mathrm{it}-2}+\boldsymbol{\beta}_{3} \mathbf{N}_{\mathrm{it}-1}+\boldsymbol{\beta}_{4} \mathbf{M}_{\mathrm{it}-1}+\boldsymbol{\beta}_{5} \mathbf{D}_{\mathrm{it}-1} \\
+\boldsymbol{\eta}_{\mathrm{t}}+\boldsymbol{\mu}_{\mathrm{i}}+\varepsilon_{\mathrm{it}}
\end{gathered}
$$

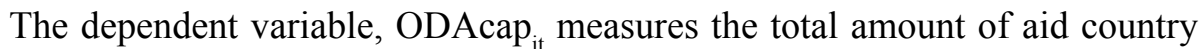
$i$ receives from all donors in period t. Specifically, disbursements of net official development assistance (ODA) or official assistance (OA) are used, minus humanitarian aid, in constant 2005 US dollars and per capita. ${ }^{2}$ The data is from the OECD (2012), thus it only includes aid from the donors which are members of the OECD's DAC, and does not include non-DAC aid from emerging donors like China or some Arab states. The independent variables in equation (1) are the following:

- dem: an event of democratisation;

- dem_lev: the level of democracy in a country;

- $\mathbf{N}$ : vector of variables measuring recipient need;

- M: vector of variables measuring recipient merit;

- D: vector of variables measuring donor interest;

- $\boldsymbol{\eta}$ : vector of time fixed effects;

- $\mu$ : vector of country fixed effects.

$1 \quad 1980$ was selected as the starting year to ensure some degree of comparability with other aid allocation studies, as many use this year as their first observation (Berthélemy - Tichit 2004; Isopi - Mavrotas 2006; Hoeffler - Outram 2011). Although political conditionality and selective aid allocation criteria where not emphasised by donors during the Cold War, this can be easily controlled for in the regressions.

2 Data on ODA disbursements are used as opposed to ODA commitments, as disbursements are a better indicator of what donors actually end up doing. As events of democratisation may often be unexpected events, donor reactions to these may not be captured in data on commitments. 
Democracy is thus measured by two variables, a "change" variable and a "level" variable. In the baseline model, both variables are derived from the Polity index from the Polity IV dataset (Marshall et al. 2011). The Polity index measures the level of autocracy and democracy on a scale of 20 , where scores of -10 to 0 denote an autocracy, 1 to 6 a partial democracy, and 7 to 10 a full democracy. The indicator has been re-scaled to a scale of 0 to 20 .

The level variable, "dem_lev" is the Polity score of the country and it is lagged two periods in the regressions. The main independent variable of interest, however, is the change variable, "dem", which is a dummy variable equalling 1 , if an event of democratic change began in the recipient country in the given three-year period. This variable is lagged one period in the regressions. It is necessarily arbitrary to provide an operationalised definition of an event of democratic change. In the baseline model, three different definitions for the change variable are used, all adapted from the definitions of democratic changes used in the Polity IV dataset. An episode of "major democratic transition" is understood as an increase in the country's Polity score of six or more points, which also involves a shift from one of the three categories above to another, i.e. from autocracy to partial democracy or full democracy, or from partial democracy to full democracy (variable major_dem). The second definition, an episode of "positive regime change" involves a three point or larger increase in the Polity score, without necessarily leading to a shift in categories (small_dem). The third definition, "any event of democratic change", simply refers to either of the two above (any_dem). By using these three definitions it is not only possible to examine how aid flows to new democracies change, but it is also possible to gauge whether autocracies that open their political systems to a certain extent, but stop short of meaningful democratisation, can count on an increase in inflows of aid.

An alternative operationalisation of democratic change is also used to test for robustness. The definitions above are not only arbitrary, but also bundle conceptually different types of democratic changes together. A shift in a country's Polity score from -10 to -7 is different than a shift from -2 to +1 . The alternative democratisation variable, "multiparty", is also a dummy, and focuses on the occurrence of multiparty elections, based on data and definitions in Cheibub et al. (2010) and Dietrich - Wright (2013). Its value is 1 , if the country holds multiparty elections resulting in real opposition parties present in an elected legislature for the first time ever, or after a previous breakdown of democracy. This variable captures only regime changes from autocracy to some form (partial or full) of democracy, and it is much more directly observable for donors than most other forms of democratic change (Dietrich - Wright 2013).

Two variables on recipient need are included. Per capita GDP at purchasing power parity is included as a proxy for the financial need of the country and the 
level of poverty (variable ppp_gdpcap). This variable, however, can be an imperfect indicator of the country's actual need, as it does not take into account the distribution of income. Following Trumbull - Wall (1994) and Bandyopadhyay - Wall (2006), a second variable, infant mortality rate per 1,000 live births is also entered, which can proxy the physical need of a recipient (inf_mort).

Besides the two democracy variables elaborated above, two further variables are used to measure recipient merit. First, annual GDP growth (gdp_growth) is included as an output side performance measure (following Berthélemy - Tichit 2004; Berthélemy 2006; Hoeffler - Outram 2011). Second, a simple measure of openness, the ratio of exports and imports to GDP is used in order to proxy "good policies", as an input side performance measure. While it has been widely debated in the literature that openness is a rather crude measure for policy quality (Rodriguez - Rodrik 2001), it is the only indicator which is available for a large range of countries and in long time series. Other widely used measures of policies and institutions are the World Bank's CPIA and Governance Matters datasets; the pre-2005 data of the former, however, are only available to World Bank researchers, and the latter is only available since 1996. A third source of institutional quality measures is the International Country Risk Guide (ICRG), which is available since 1984, but only for a rather small group of countries. Neither of the above measures are therefore suitable, and one must make do with the imperfect openness measure. None the less, the "investment profile" index from the ICRG is used in robustness checks.

Operationalising donor interests on the aggregate level can be difficult as different donors have different interests and finding suitable proxies on the aggregate level under analysis can be difficult. In case of political interests, it has been argued (see, for example, Alesina - Dollar 2000) that donors give more aid to former colonies, thus a dummy to indicate whether a country was a colony of any OECD DAC donor after 1900 is included (variable colony). As a further measure of political donor interests, dummies for various regions are also included, namely for Sub-Saharan Africa, Latin America, the Middle East and North Africa, and Europe (and thus Asian countries represent the baseline; variables africa, latin_am, mena and europe, respectively). These dummies can proxy the special interests that some donors have towards specific regions, such as the United States towards Latin America, or the European countries towards Africa. Dummy variables are also added for two well-known outliers, Israel and Egypt (Alesina - Dollar 2000). Economic donor interests are proxied with two variables: the stock of FDI relative to GDP in the country (variable fdi_stock; Maizels - Nissanke 1984; Berthélemy 2006), as well as the imports of the recipient from high-income countries, again compared to GDP (variable hi_inc_imports; Younas 2008). 
One further control variable, the level of population in the recipient country is also added to account for the fact that less populous countries can receive higher per capita amounts of aid due to the high fixed costs of development cooperation. Time dummies for each three-year period are also used. Several further variables are used for robustness checks, but these are discussed in the following section. All nominal price and exchange rate data have been converted to constant 2005 dollars. The dependent variable as well as per capita GDP and population are entered in natural logarithm. All variables are taken from the World Bank's World Development Indicators database (World Bank 2012), with the exception of the dependent variable, which is from the OECD (2012), and the democracy variables from the Polity IV dataset (Cheibub et al. 2010; Marshall et al. 2011; Dietrich - Wright 2013).

\subsection{Estimation issues}

A major problem in estimating aid allocation equations like (1) is endogenity, resulting mainly from two-way causation between aid and most of the independent variables, a case illustrated with aid and democracy in the previous section. Sadly, there is no perfect method for dealing with this problem. One possibility is to lag the independent variables, which may allow capturing their effects in time on the dependent variable. This also makes sense from an economic point of view, as donors most likely make aid allocation decisions based on data from previous years. Another possibility is to use instrumental variables techniques, but the main problem here is that so far no variables have been identified that can serve as good instruments, and in fact it is unlikely that they even exist.

When estimating equation (1), the independent variables are entered as first lags and the democratisation "level" variable as a second lag as discussed in Section 3.1, as a solution for treating endogenity. However, the problem of endogenity in the relationship between aid and democratic change is mitigated to some extent by one further issue. It can be argued that the main independent variable of interest, an event of democratic change, is actually rather exogenous to aid flows. While the level of democracy in a country may not be fully exogenous to aid flows, an event of democratic change is. The timing of an event of democratisation often depends on random events like riots against police brutality, or democratisation spilling over from neighbouring countries. The Arab Spring revolutions show this well: in Tunisia, the "Jasmine Revolution" after Mohamed Bouazizi's self-immolation in response to police abuse, sparking riots among a population already upset due to rising food prices. The example of Tunisia quickly spread to other Arab countries, leading to political change in Egypt and Libya. 
Concerning estimation methods, it is only a slight exaggeration to say that almost all econometric methods have been tried in the aid allocation literature, ranging from simple and pooled OLS (Maizels - Nissanke 1984; Wall 1995; Alesina Dollar 2000; Neumayer 2003b; Dollar - Levin 2006; Younas 2008) through more sophisticated panel methods like fixed effects (Trumbull - Wall 1994; Neumayer 2003c; Bandyopadhyay - Wall 2006) and random effects (Neumayer 2003c) to instrumental variable panel methods like 2SLS with fixed effects, although only for a special case where instruments were actually available (Chauvet 2002). Papers using bilateral aid flows instead of aggregate aid flows must also cope with the censored nature of the dependent variable, as not all countries receive aid from every donor. Berthélemy (2006), for example, recommends using either a Tobit model or two-step methods like Heckmann estimation in these cases. This is, however, not an issue in the current case of using aggregate aid flows from all donors, as basically every country in the dataset receives some amount of aid in every three-year period. There were only five recipient-periods (out of the potential dataset of 1,360 observations) which did not receive any aid; in these cases, a minuscule amount of 0.01 million dollars divided by the country's population was added. It is unlikely that this would bias the results.

To ensure the robustness of results, equation (1) is estimated with three different methods. First, pooled OLS is used, which is clearly not an ideal method for estimating panel equations, but it can serve as useful baseline. Second, the equation is estimated with random effects, which is suited to the panel nature of the data and allows the estimation of time-invariant variables. However, random effects assume that the time-invariant country effects are orthogonal to the error term, an assumption which is most likely not valid. Thus, the third (and preferred) method is the fixed effects panel estimator, which can control for time-invariant donor political and strategic interests by first-differencing the equation (Trumbull - Wall 1994). The downside of fixed effects is that the effects of the timeinvariant variables cannot be estimated, but none of these variables are of primary interest in this case.

\section{EMPIRICAL RESULTS}

\subsection{Descriptive statistics}

Our dataset includes 73 events of major democratic transitions and 47 positive regime changes, the geographic and temporal distribution of which are shown in Table 1 . There are 111 events which satisfy the conditions of the multiparty elections control variable. 
Table 1. Number of major democratic changes and positive regime changes by regions and decades

\begin{tabular}{l|c|c|c|c|c|c|c}
\hline & \multicolumn{6}{|c|}{ Major democratic transitions } & \multicolumn{2}{c|}{ Positive regime changes } & \multirow{2}{*}{\begin{tabular}{l} 
Total \\
\cline { 2 - 8 }
\end{tabular}} & $\begin{array}{c}1980- \\
1988\end{array}$ & $\begin{array}{c}1989- \\
2000\end{array}$ & $\begin{array}{c}2001- \\
2009\end{array}$ & $\begin{array}{c}1980- \\
1988\end{array}$ & $\begin{array}{c}1989- \\
2000\end{array}$ & $\begin{array}{c}2001- \\
2009\end{array}$ & \\
\hline Asia and Oceania & 2 & 7 & 5 & 5 & 1 & 3 & 23 \\
\hline Europe & 0 & 10 & 0 & 0 & 3 & 1 & 14 \\
\hline $\begin{array}{l}\text { Middle East and } \\
\text { North Africa }\end{array}$ & 1 & 1 & 0 & 2 & 5 & 2 & 11 \\
\hline Latin America & 8 & 8 & 1 & 2 & 2 & 0 & 21 \\
\hline Sub-Saharan Africa & 2 & 21 & 7 & 0 & 15 & 6 & 51 \\
\hline Total & 13 & 47 & 13 & 9 & 26 & 12 & 120 \\
\hline
\end{tabular}

Note: $1980-88$ represents periods 1,2 and 3; 1989-2000 periods $4,5,6$ and 7; 2001-2009 periods 8,9 and 10 of the dataset.

Source: Based on Marshall et al. (2011).

Table 2 shows how average levels of aid per capita changed during and after these democratic transitions, again in regional breakdown. The table uses the three-year averages approach described in Section 3. "Before" and "after" averages represent three-year periods before and after a three-year period during which an event of democratic change began. Data for each three-year "before", "during", and "after" period were averaged across regions, using country populations as weights. Results in Table 2 indicate that donors have reacted differently to democratisations in different regions. Both types of democratic changes were followed by increases in aid in Europe and Latin-America, and major transitions were also rewarded in Asia. The strong changes in aid to European countries are actually even downplayed by the data, as many countries which gained their independence in parallel to becoming democratic (such as the successor states of

Table 2. Average regional aid per capita levels before, during and after democratisation episodes (at 2005 constant dollars and exchange rates)

\begin{tabular}{l|c|c|c|c|c|c}
\hline \multirow{2}{*}{} & \multicolumn{3}{|c|}{ Major democratic transitions } & \multicolumn{3}{c}{ Positive regime changes } \\
\cline { 2 - 7 } & Before & During & After & Before & During & After \\
\hline Asia and Oceania & 13.2 & 13.7 & 15.0 & 15.7 & 13.4 & 13.6 \\
\hline Europe & 3.0 & 39.3 & 44.3 & 29.8 & 30.6 & 41.6 \\
\hline $\begin{array}{l}\text { Middle East and } \\
\text { North Africa }\end{array}$ & 16.4 & 6.3 & 5.6 & 36.2 & 32.9 & 27.1 \\
\hline Latin America & 7.5 & 12.9 & 15.7 & 17.1 & 18.3 & 23.2 \\
\hline Sub-Saharan Africa & 46.6 & 44.4 & 35.2 & 43.5 & 37.4 & 34.4 \\
\hline
\end{tabular}

Note: Each "before”, “during”, "after” period represents three-year population weighted averages.

Source: Calculations based on data from OECD (2012) and Marshall et al. (2011). 
Table 3. Correlation matrix of main variables

\begin{tabular}{|c|c|c|c|c|c|c|c|c|}
\hline & $\begin{array}{c}\ln \\
\text { ODA_- } \\
\text { cap }\end{array}$ & $\frac{\ln }{\text { population }}$ & polity & $\begin{array}{l}\text { inf } \\
\text { mort }\end{array}$ & $\begin{array}{l}\text { fdi } \\
\text { stock }\end{array}$ & openness & $\underset{\text { gdpcap }}{\ln \_ \text {ppp }}$ & $\underset{\text { growth }}{\text { gdp }}$ \\
\hline ln_population & -0.54 & 1.00 & & & & & & \\
\hline dem_lev & 0.02 & -0.01 & 1.00 & & & & & \\
\hline inf_mort & 0.26 & 0.05 & -0.40 & 1.00 & & & & \\
\hline fdi_stock & 0.05 & -0.13 & 0.04 & 0.04 & 1.00 & & & \\
\hline openness & 0.12 & -0.43 & 0.05 & -0.36 & 0.24 & 1.00 & & \\
\hline ln_ppp_gdpcap & -0.31 & -0.14 & 0.22 & -0.78 & -0.05 & 0.38 & 1.00 & \\
\hline gdp_growth & -0.02 & 0.06 & -0.02 & -0.06 & 0.29 & 0.13 & 0.04 & 1.00 \\
\hline hi_inc_imports & -0.01 & -0.04 & -0.12 & -0.05 & 0.08 & 0.08 & 0.26 & 0.07 \\
\hline
\end{tabular}

Source: Calculations based on data from OECD (2012), WDI (2012) and Marshall et al. (2011).

the former Soviet Union, Yugoslavia, and Czechoslovakia) are not included in the data. However, neither type of democratisation was followed by higher aid per capita levels in Sub-Saharan Africa or the Middle East and North Africa.

However, one should not draw any strong conclusions based on the data in Table 2. Simple before-after data can be powerful, but also misleading, as they do not account for the effects of other factors. Democratic transitions may be accompanied by a strong recession (as was the case in Central and Eastern Europe in the early 1990s), increasing poverty, or violent conflict, each of which may have an impact on aid flows. Also, even though the regional averages may suggest otherwise, there are examples in the data of cases even in Sub-Saharan Africa, where donors have increased aid flows after an event of democratisation (such as Zambia in 1991). In addition, the three-year averages may hide some changes in aid, as donors may react much more quickly to democratic changes.

Coefficients of correlation between the main dependent variable and the independent variables are shown in Table 3.

\subsection{Results and sensitivity analysis}

Table 4 shows the results of estimating the baseline model in equation (1) and also includes some sensitivity tests. Model 1 estimates the equation using pooled OLS. Looking first at the main variable of interest, an event of any democratic change is significant and its coefficient is economically meaningful, as it implies that a country undertaking democratic reforms can, ceteris paribus, expect an approximately $26 \%$ increase in aid per capita. The level of democracy is also 
Table 4. Estimation results of aid allocation regressions

\begin{tabular}{|c|c|c|c|c|c|c|c|c|}
\hline & $\begin{array}{l}(1) \\
\text { Pooled } \\
\text { OLS }\end{array}$ & $\begin{array}{c}(2) \\
\text { Random } \\
\text { effects }\end{array}$ & $\begin{array}{l}(3) \\
\text { Fixed } \\
\text { effects }\end{array}$ & $\begin{array}{l}\text { (4) } \\
\text { Fixed } \\
\text { effects }\end{array}$ & $\begin{array}{l}(5) \\
\text { Fixed } \\
\text { effects }\end{array}$ & $\begin{array}{l}\text { (6) } \\
\text { Fixed } \\
\text { effects }\end{array}$ & $\begin{array}{l}(7) \\
\text { Fixed } \\
\text { effects }\end{array}$ & $\begin{array}{c}(8) \\
\text { Fixed } \\
\text { effects }\end{array}$ \\
\hline ln_population ${ }_{t-1}$ & \begin{tabular}{|l|}
$-0.585^{* * *}$ \\
$(-20.818)$ \\
\end{tabular} & $\begin{array}{c}-0.585 * * * \\
(-10.292) \\
\end{array}$ & \begin{tabular}{|l}
$-3.422 * * *$ \\
$(-2.712)$ \\
\end{tabular} & \begin{tabular}{|l}
$-3.409 * *$ \\
$(-2.425)$ \\
\end{tabular} & \begin{tabular}{|l|}
$-3.425^{* * *}$ \\
$(-2.707)$ \\
\end{tabular} & \begin{tabular}{|l|}
$-2.544 * * *$ \\
$(-2.979)$ \\
\end{tabular} & \begin{tabular}{|l|}
$-3.432 * * *$ \\
$(-2.699)$ \\
\end{tabular} & \begin{tabular}{|l}
$-3.416 * * *$ \\
$(-2.693)$ \\
\end{tabular} \\
\hline dem_lev ${ }_{t-2}$ & \begin{tabular}{|l|}
$0.025^{* * * *}$ \\
$(3.033)$ \\
\end{tabular} & \begin{tabular}{|l|}
$0.027^{*}$ \\
$(1.785)$ \\
\end{tabular} & \begin{tabular}{|c|}
0.016 \\
$(1.340)$ \\
\end{tabular} & \begin{tabular}{|l|}
0.017 \\
$(1.252)$ \\
\end{tabular} & \begin{tabular}{|c|}
0.016 \\
$(1.300)$ \\
\end{tabular} & \begin{tabular}{|c|}
0.013 \\
$(1.185)$ \\
\end{tabular} & \begin{tabular}{|c|}
0.019 \\
$(1.397)$ \\
\end{tabular} & \begin{tabular}{|c|}
0.012 \\
$(1.070)$ \\
\end{tabular} \\
\hline any_dem ${ }_{t-1}$ & \begin{tabular}{|l|}
$0.262 * *$ \\
$(2.509)$ \\
\end{tabular} & $\begin{array}{l}0.260 * * * \\
(2.669) \\
\end{array}$ & \begin{tabular}{|l}
$0.250 * *$ \\
$(2.508)$ \\
\end{tabular} & $\begin{array}{l}0.292 * * * \\
(2.711) \\
\end{array}$ & \begin{tabular}{|l|}
$0.254 * *$ \\
$(2.524)$ \\
\end{tabular} & \begin{tabular}{|c|}
$0.224 * *$ \\
$(2.432)$ \\
\end{tabular} & \begin{tabular}{|l}
$0.252 * *$ \\
$(2.529)$ \\
\end{tabular} & - \\
\hline multiparty $_{\mathrm{t}-1}$ & - & - & - & - & - & - & - & \begin{tabular}{|c|c|}
$0.186^{* * *}$ \\
$(2.127)$ \\
\end{tabular} \\
\hline inf_mort $_{t-1}$ & $\begin{array}{l}-0.001 \\
(-0.489) \\
\end{array}$ & $\begin{array}{c}0.000 \\
(0.068) \\
\end{array}$ & \begin{tabular}{|l}
-0.008 \\
$(-1.476)$ \\
\end{tabular} & \begin{tabular}{|l}
-0.007 \\
$(-1.027)$ \\
\end{tabular} & \begin{tabular}{|l}
-0.007 \\
$(-1.251)$ \\
\end{tabular} & \begin{tabular}{|l}
-0.007 \\
$(-1.321)$ \\
\end{tabular} & \begin{tabular}{|l}
-0.008 \\
$(-1.531)$ \\
\end{tabular} & \begin{tabular}{|l}
-0.008 \\
$(-1.378)$ \\
\end{tabular} \\
\hline colony & $\begin{array}{c}0.036 \\
(0.263) \\
\end{array}$ & \begin{tabular}{|l|l}
-0.079 \\
$(-0.323)$ \\
\end{tabular} & - & - & - & - & - & - \\
\hline fdi_stock ${ }_{t-1}$ & \begin{tabular}{|l}
$-0.003 * * *$ \\
$(-3.789)$ \\
\end{tabular} & $\begin{array}{l}-0.002 * * * \\
(-2.717) \\
\end{array}$ & $\begin{array}{l}-0.002 * * * \\
(-3.018) \\
\end{array}$ & \begin{tabular}{|l}
$-0.003 * * *$ \\
$(-2.840)$ \\
\end{tabular} & \begin{tabular}{|l}
$-0.002^{* * *}$ \\
$(-3.033)$ \\
\end{tabular} & $\begin{array}{l}-0.001 \\
(-0.710) \\
\end{array}$ & \begin{tabular}{|l}
$-0.002^{* * *}$ \\
$(-3.069)$ \\
\end{tabular} & $\begin{array}{l}-0.002 * * * \\
(-2.858) \\
\end{array}$ \\
\hline openness $_{t-1}$ & \begin{tabular}{|l}
$0.004 * * *$ \\
$(2.926)$ \\
\end{tabular} & \begin{tabular}{|l|}
$0.004 * *$ \\
$(2.425)$ \\
\end{tabular} & \begin{tabular}{|l|l}
$0.005^{* *}$ \\
$(2.434)$ \\
\end{tabular} & \begin{tabular}{|l|}
0.003 \\
$(1.093)$ \\
\end{tabular} & \begin{tabular}{|l|}
$0.005^{* *}$ \\
$(2.267)$ \\
\end{tabular} & \begin{tabular}{|c|}
0.003 \\
$(1.518)$ \\
\end{tabular} & \begin{tabular}{|l|}
$0.005^{* *}$ \\
$(2.449)$ \\
\end{tabular} & \begin{tabular}{|c|c|}
$0.005^{* *}$ \\
$(2.540)$ \\
\end{tabular} \\
\hline africa & $\begin{array}{c}0.135 \\
(1.132) \\
\end{array}$ & $\begin{array}{c}0.244 \\
(0.823) \\
\end{array}$ & - & - & - & - & - & - \\
\hline latin_am & \begin{tabular}{|l}
$0.458^{* * * *}$ \\
$(2.943)$ \\
\end{tabular} & $\begin{array}{c}0.290 \\
(0.859) \\
\end{array}$ & - & - & - & - & - & - \\
\hline europe & \begin{tabular}{|l|}
$0.946 * * *$ \\
$(4.266)$ \\
\end{tabular} & \begin{tabular}{|l}
$0.860^{* *}$ \\
$(2.483)$ \\
\end{tabular} & - & - & - & - & - & - \\
\hline mena & \begin{tabular}{|l}
$0.824 * * *$ \\
$(4.393)$ \\
\end{tabular} & $\begin{array}{c}0.445 \\
(1.013) \\
\end{array}$ & - & - & - & - & - & - \\
\hline Israel & \begin{tabular}{|l}
$3.676^{* * * *}$ \\
$(13.549)$ \\
\end{tabular} & $\begin{array}{l}3.292 * * * \\
(7.736) \\
\end{array}$ & - & - & - & - & - & - \\
\hline Egypt & \begin{tabular}{|l}
$2.167^{* * * *}$ \\
$(10.664)$ \\
\end{tabular} & $\begin{array}{l}2.145^{* * *} \\
(6.189) \\
\end{array}$ & - & - & - & - & - & - \\
\hline ln_ppp_gdpcap ${ }_{t-1}$ & \begin{tabular}{|l|}
$-0.945^{* * *}$ \\
$(-9.602)$ \\
\end{tabular} & $\begin{array}{l}-0.787 * * * \\
(-4.485) \\
\end{array}$ & \begin{tabular}{|l}
$-0.723 * * * *$ \\
$(-3.225)$ \\
\end{tabular} & \begin{tabular}{|l}
$-0.941 * * *$ \\
$(-2.844)$ \\
\end{tabular} & \begin{tabular}{|l|l}
$-0.758^{* * *}$ \\
$(-3.263)$ \\
\end{tabular} & \begin{tabular}{|l}
$-0.739^{* *}$ \\
$(-2.591)$ \\
\end{tabular} & \begin{tabular}{|l|l}
$-0.730^{* * * *}$ \\
$(-3.208)$ \\
\end{tabular} & \begin{tabular}{|l}
$-0.725^{* * *}$ \\
$(-3.131)$ \\
\end{tabular} \\
\hline gdp_growth $_{t-1}$ & \begin{tabular}{|c|}
0.006 \\
$(0.862)$ \\
\end{tabular} & $\begin{array}{c}0.004 \\
(0.629) \\
\end{array}$ & \begin{tabular}{|l|l}
-0.002 \\
$(-0.230)$
\end{tabular} & \begin{tabular}{|l|l}
-0.006 \\
$(-0.470)$ \\
\end{tabular} & \begin{tabular}{|l|}
-0.003 \\
$(-0.337)$ \\
\end{tabular} & $\begin{array}{c}0.004 \\
(0.537) \\
\end{array}$ & $\begin{array}{l}-0.001 \\
(-0.166) \\
\end{array}$ & \begin{tabular}{|l|l}
-0.003 \\
$(-0.332)$ \\
\end{tabular} \\
\hline hi_inc_imports $s_{t-1}$ & \begin{tabular}{|l|}
$0.008 * * *$ \\
$(3.167)$ \\
\end{tabular} & \begin{tabular}{|l|}
0.008 \\
$(1.484)$ \\
\end{tabular} & \begin{tabular}{|l}
0.002 \\
$(0.226)$ \\
\end{tabular} & \begin{tabular}{|l|}
0.007 \\
$(0.818)$ \\
\end{tabular} & \begin{tabular}{|c|}
0.001 \\
$(0.201)$ \\
\end{tabular} & \begin{tabular}{|c|}
0.007 \\
$(1.024)$ \\
\end{tabular} & \begin{tabular}{|c|}
0.002 \\
$(0.264)$ \\
\end{tabular} & \begin{tabular}{|c|}
0.002 \\
$(0.209)$ \\
\end{tabular} \\
\hline inv_prot ${ }_{t-1}$ & - & - & - & \begin{tabular}{|l|l}
-0.008 \\
$(-0.232)$ \\
\end{tabular} & - & - & - & - \\
\hline conflict & - & - & - & - & \begin{tabular}{|l}
-0.032 \\
$(-1.486)$ \\
\end{tabular} & - & - & - \\
\hline military exp & - & - & - & - & - & \begin{tabular}{|l}
-0.002 \\
$(-0.154)$ \\
\end{tabular} & - & - \\
\hline $\begin{array}{l}\text { cold_war*any_ } \\
\text { dem }\end{array}$ & - & - & - & - & - & - & \begin{tabular}{|c|}
0.255 \\
$(1.270)$ \\
\end{tabular} & - \\
\hline constant & \begin{tabular}{|l|}
$18.861^{* * * *}$ \\
$(23.841)$ \\
\end{tabular} & \begin{tabular}{|l|}
$17.534 * * *$ \\
$(10.533)$ \\
\end{tabular} & \begin{tabular}{|l}
$64.237 * * *$ \\
$(3.020)$ \\
\end{tabular} & \begin{tabular}{|l}
$66.492 * * *$ \\
$(2.656)$ \\
\end{tabular} & \begin{tabular}{|l|}
$64.657^{* * * *}$ \\
$(3.023)$ \\
\end{tabular} & \begin{tabular}{|l|}
$50.183^{* * *}$ \\
$(3.321)$ \\
\end{tabular} & \begin{tabular}{|l}
$64.414 * * *$ \\
$(3.004)$ \\
\end{tabular} & \begin{tabular}{|l}
$64.175^{* * *}$ \\
$(2.998)$ \\
\end{tabular} \\
\hline $\mathrm{N}$ & 917 & 917 & 917 & 671 & 908 & 746 & 917 & 917 \\
\hline $\mathrm{R}^{2}$ & 0.57 & 0.54 & 0.34 & 0.30 & 0.32 & 0.38 & 0.34 & 0.34 \\
\hline
\end{tabular}

Notes: *** significant at $1 \%, * * 5 \%, * 10 \%$ level, respectively. T-statistics are shown in parentheses. All models estimated with heteroskedasticity robust standards errors. Models include period dummies (not reported), which are jointly significant in all cases at the $1 \%$ level. 
significant, showing that more democratic countries receive more aid, although not much more: a 1 point improvement on the Polity scale implies a modest $2.5 \%$ increase in aid.

The pooled OLS model also confirms some basic expectations and previous findings of the literature. GDP per capita and the population of the recipient country are both highly significant. The openness variable is also a significant determinant of aid per capita flows. The trade variable turns out to be significant too, implying that those countries that import more from high income countries also get more aid. The FDI stock variable, on the other hand, is significant but with a negative sign, which means that FDI and aid are rather substitutes to each other. Countries with higher FDI stocks receive lower per capita aid. These results indicate that economic donor self-interests may be at play in the case of trade, but not in the case of FDI.

As explained above, pooled OLS is not the best estimator. In order to mitigate the bias caused by unobserved country effects to some extent, model 1 also includes dummy variables for these fixed effects, as outlined in Section 3. The regional dummies are significant for the relatively higher income regions, Europe, Latin-America, and the Middle East and North Africa. Interestingly, the dummy on colonial past is not significant, a finding which contradicts some of the previous literature (such as Alesina - Dollar 2000). The most likely reason for this contradiction is the different time periods used in the analyses. As the panel in this paper includes data up to 2009, it may be possible that the gradual shift away from giving disproportional amounts of aid to former colonies by donors like France and the UK, apparent since the late 1990s (Pacquement 2010), dominates the data.

Model 2 uses the random effects estimator. The significance of the democratic change variable increases in this model and its coefficient practically remains the same. The level of democracy is still significant, although only at the $10 \%$ level. The significance of some other variables also changes in the random effects model, the Latin America and North Africa and Middle East dummies, as well as the variable on imports from high income countries are no longer significant.

In model 3, the preferred fixed effects estimator is used. A Hausmann test confirms that fixed effects is indeed a better estimator than random effects $\left(\chi^{2}=\right.$ $56.24, \mathrm{p}=0.00$ ). The model confirms the findings of the previous models for the democratic change variable. There is, however, one important change. The level of democracy variable now loses its significance. This result can indicate that donors do not actually give more aid to more democratic countries, but they do increase aid to countries undergoing democratic change. This can also imply that previous results in the literature on the significance of the level of democracy 
were driven by changes in democracy within countries rather than differences across countries.

In order to check the robustness of the results in model 3, several further control variables were introduced that may influence donor allocation decisions. Models 4 to 7 include these tests. In model 4, a variable on the investment profile of the recipient country is introduced, taken from ICRG (variable inv_pro). This measure includes assessments on the rule of law in a country, the risk of expropriation and the viability of contracts, and thus can be thought of as an indicator of the quality of economic institutions in the country. It is measured on a scale of 0 to 12, with higher numbers representing a less risky investment environment. The downside of the indicator, however, is that its time series is only available from 1984 and covers a lower number of countries, thus greatly reducing the number of observations in the model. Despite this problem, the results on the democratic change variable do not change, and the inv_pro variable is insignificant. The variable on openness, however, loses its significance, which is likely due to the fact that it is highly correlated with the new variable and the estimator is not able to sufficiently differentiate between their effects. In model 5, a variable measuring the intensity of civilian and international conflicts in a recipient is introduced, taken from Marshall (2012). This variable is not significant either and does not alter the results. Model 6 adds a variable on military expenditures per GDP from the World Development Indicators, which again greatly reduces the number of observations, causing the FDI and openness variables to lose their significance. However, the new variable is not significant and it does not affect the significance of the democratic change variable. Finally, in model 7, an interaction variable between the democratic change dummy and a dummy for the period of the Cold War is included. The logic of this is that donors may have been less sensitive to rewarding democratic change during the Cold War, as strategic concerns were more dominant. However, this variable is insignificant too and does not change the results.

Model 8 uses same specification as model 3, but with the alternative measure for democratic change, i.e. holding multiparty elections for the first time, also lagged one period. The multiparty variable is significant, although the size of the coefficient is smaller than that of the any_dem variable in model 3. The significance of the other variables does not change. All the previous regressions (models 4 to 7) were also re-run with multiparty variable, and it turned out to be significant in all cases (these results are not reported). This indicates that our results hold irrespective of how democratisation is operationalised.

As a further step in the sensitivity analysis, the variable on democratic change from the Polity dataset was broken up according to the two definitions outlined in Section 3, i.e. major democratic transitions and positive regime changes. These results are included in model 9 in Table 5. The disaggregation of the democratic 
Table 5. Estimation results of aid allocation regressions

\begin{tabular}{|c|c|c|c|c|c|c|}
\hline & $\begin{array}{c}(9) \\
\text { Fixed effects } \\
\end{array}$ & $\begin{array}{c}(10) \\
\text { Fixed effects } \\
\end{array}$ & $\begin{array}{c}(11) \\
\text { Fixed effects }\end{array}$ & $\begin{array}{c}(12) \\
\text { Fixed effects }\end{array}$ & $\begin{array}{c}(13) \\
\text { Fixed effects }\end{array}$ & $\begin{array}{c}(14) \\
\text { Fixed effects }\end{array}$ \\
\hline $\ln \_$population $_{t-1}$ & $\begin{array}{l}-3.424 * * * \\
(-2.713) \\
\end{array}$ & $\begin{array}{l}-3.069 * * * \\
(-2.622) \\
\end{array}$ & $\begin{array}{l}-3.797 * * * \\
(-3.653) \\
\end{array}$ & $\begin{array}{l}-3.498 * * * \\
(-2.711) \\
\end{array}$ & $\begin{array}{l}-3.394 * * * \\
(-2.712) \\
\end{array}$ & $\begin{array}{l}-3.457 * * * \\
(-2.741) \\
\end{array}$ \\
\hline dem_lev $\mathrm{t}_{\mathrm{t}-2}$ & $\begin{array}{c}0.017 \\
(1.344) \\
\end{array}$ & - & - & $\begin{array}{c}0.021 \\
(1.483) \\
\end{array}$ & $\begin{array}{c}0.022 \\
(1.610) \\
\end{array}$ & $\begin{array}{c}0.021 \\
(1.519) \\
\end{array}$ \\
\hline dem_lev $v_{t-3}$ & - & $\begin{array}{c}0.005 \\
(0.413) \\
\end{array}$ & - & - & - & - \\
\hline dem_lev $\mathrm{t}_{\mathrm{t}-6}$ & - & - & $\begin{array}{c}0.022 \\
(1.893) \\
\end{array}$ & - & - & - \\
\hline major_dem ${ }_{t-1}$ & $\begin{array}{l}0.307 * * * \\
(2.617) \\
\end{array}$ & $\begin{array}{l}0.245^{* *} \\
(2.236) \\
\end{array}$ & $\begin{array}{l}0.227 * * \\
(2.074) \\
\end{array}$ & $\begin{array}{r}0.181^{*} \\
(1.915) \\
\end{array}$ & $\begin{array}{l}0.310^{* * *} \\
(2.622)\end{array}$ & $\begin{array}{l}0.296 * * \\
(2.455) \\
\end{array}$ \\
\hline major_dem ${ }_{t-2}$ & - & $\begin{array}{c}0.202 \\
(1.355) \\
\end{array}$ & $\begin{array}{l}0.315 * * * \\
(2.665) \\
\end{array}$ & - & - & - \\
\hline major_dem ${ }_{t-3}$ & - & - & $\begin{array}{l}0.354 * * * \\
(2.999)\end{array}$ & - & - & - \\
\hline major_dem ${ }_{t-4}$ & - & - & $\begin{array}{c}0.287 * * \\
(2.075) \\
\end{array}$ & - & - & - \\
\hline major_dem $_{t-5}$ & - & - & $\begin{array}{c}0.218 \\
(1.523) \\
\end{array}$ & - & - & - \\
\hline small_dem ${ }_{t-1}$ & $\begin{array}{c}0.172 \\
(1.224) \\
\end{array}$ & $\begin{array}{c}0.182 \\
(1.308) \\
\end{array}$ & $\begin{array}{c}0.074 \\
(0.862) \\
\end{array}$ & $\begin{array}{c}0.186 \\
(1.316) \\
\end{array}$ & $\begin{array}{c}0.172 \\
(1.207) \\
\end{array}$ & $\begin{array}{c}0.190 \\
(1.349) \\
\end{array}$ \\
\hline small_dem ${ }_{t-2}$ & - & $\begin{array}{c}0.083 \\
(0.769) \\
\end{array}$ & $\begin{array}{c}0.137 \\
(1.497) \\
\end{array}$ & - & - & - \\
\hline small_dem $_{t-3}$ & - & - & $\begin{array}{l}0.276 * * * \\
(3.142) \\
\end{array}$ & - & - & - \\
\hline small_dem $_{t-4}$ & - & - & $\begin{array}{r}0.168^{*} \\
(1.761) \\
\end{array}$ & - & - & - \\
\hline small_dem ${ }_{t-5}$ & - & - & $\begin{array}{c}0.192 * \\
(1.806) \\
\end{array}$ & - & - & - \\
\hline dem_revers ${ }_{t-1}$ & - & - & - & - & $\begin{array}{l}-0.299^{* *} \\
(-2.475)\end{array}$ & $\begin{array}{l}-0.279^{* *} \\
(-2.286)\end{array}$ \\
\hline major_dem*africa & - & - & - & $\begin{array}{c}-0.116 \\
(-1.012) \\
\end{array}$ & - & - \\
\hline major_dem*latin_am & - & - & - & $\begin{array}{l}0.301 * * \\
(1.986)\end{array}$ & - & - \\
\hline major_dem *europe & - & - & - & $\begin{array}{c}0.802 * \\
(1.773) \\
\end{array}$ & - & - \\
\hline major_dem *mena & - & - & - & $\begin{array}{l}0.602 * * * \\
(3.800)\end{array}$ & - & - \\
\hline inf_mort $_{\mathrm{t}-1}$ & $\begin{array}{c}-0.008 \\
(-1.462) \\
\end{array}$ & $\begin{array}{c}-0.011 * \\
(-1.929) \\
\end{array}$ & $\begin{array}{c}-0.009^{*} \\
(-1.782) \\
\end{array}$ & $\begin{array}{c}-0.008 \\
(-1.402) \\
\end{array}$ & $\begin{array}{c}-0.007 \\
(-1.324) \\
\end{array}$ & $\begin{array}{c}-0.006 \\
(-1.034) \\
\end{array}$ \\
\hline fdi_stock ${ }_{t-1}$ & $\begin{array}{l}-0.002 * * * \\
(-2.924)\end{array}$ & $\begin{array}{l}-0.002 * * \\
(-2.469)\end{array}$ & $\begin{array}{c}-0.001 \\
(-0.403) \\
\end{array}$ & $\begin{array}{l}-0.002 * * * \\
(-2.921)\end{array}$ & $\begin{array}{l}-0.002 * * * \\
(-2.870)\end{array}$ & $\begin{array}{l}-0.002 * * * \\
(-2.849)\end{array}$ \\
\hline openness $_{t-1}$ & $\begin{array}{l}0.005^{* *} \\
(2.410) \\
\end{array}$ & $\begin{array}{c}0.003^{*} \\
(1.740) \\
\end{array}$ & $\begin{array}{c}0.003 \\
(1.580) \\
\end{array}$ & $\begin{array}{l}0.004 * * \\
(2.270) \\
\end{array}$ & $\begin{array}{l}0.004 * * \\
(2.200) \\
\end{array}$ & $\begin{array}{l}0.004 * * \\
(2.106) \\
\end{array}$ \\
\hline ln_ppp_gdpcap $p_{t-1}$ & $\begin{array}{l}-0.722 * * * \\
(-3.193) \\
\end{array}$ & $\begin{array}{l}-0.704 * * * \\
(-2.848)\end{array}$ & $\begin{array}{l}-0.370^{* *} \\
(-2.091)\end{array}$ & $\begin{array}{l}-0.741^{* * *} \\
(-3.178) \\
\end{array}$ & $\begin{array}{l}-0.724 * * * \\
(-3.184) \\
\end{array}$ & $\begin{array}{l}-0.791 * * * \\
(-3.285)\end{array}$ \\
\hline gdp_growth $_{t-1}$ & $\begin{array}{c}-0.002 \\
(-0.216) \\
\end{array}$ & $\begin{array}{c}-0.003 \\
(-0.391) \\
\end{array}$ & $\begin{array}{c}0.000 \\
(0.149) \\
\end{array}$ & $\begin{array}{c}-0.001 \\
(-0.135) \\
\end{array}$ & $\begin{array}{c}-0.003 \\
(-0.351) \\
\end{array}$ & $\begin{array}{c}-0.005 \\
(-0.566) \\
\end{array}$ \\
\hline hi_inc_imports ${ }_{t-1}$ & $\begin{array}{c}0.002 \\
(0.226) \\
\end{array}$ & $\begin{array}{c}0.006 \\
(0.766) \\
\end{array}$ & $\begin{array}{c}0.006 \\
(0.963) \\
\end{array}$ & $\begin{array}{c}0.003 \\
(0.378) \\
\end{array}$ & $\begin{array}{c}0.001 \\
(0.186) \\
\end{array}$ & $\begin{array}{c}0.001 \\
(0.082) \\
\end{array}$ \\
\hline
\end{tabular}


Table 5. continued

\begin{tabular}{l|c|c|c|c|c|c}
\hline & $\begin{array}{c}(9) \\
\text { Fixed effects }\end{array}$ & $\begin{array}{c}(10) \\
\text { Fixed effects }\end{array}$ & $\begin{array}{c}(11) \\
\text { Fixed effects }\end{array}$ & $\begin{array}{c}(12) \\
\text { Fixed effects }\end{array}$ & $\begin{array}{c}(13) \\
\text { Fixed effects }\end{array}$ & $\begin{array}{c}(14) \\
\text { Fixed effects }\end{array}$ \\
\hline conflict & - & - & - & - & - & $\begin{array}{c}-0.047^{*} \\
(-1.853)\end{array}$ \\
\hline constant & $64.250^{* * *}$ & $58.476^{* * *}$ & $65.173^{* * *}$ & $65.520^{* * *}$ & $63.754^{* * *}$ & $65.443^{* * *}$ \\
& $(3.021)$ & $(2.931)$ & $(3.657)$ & $(3.010)$ & $(3.023)$ & $(3.059)$ \\
\hline $\mathrm{N}$ & 917 & 822 & 2,389 & 917 & 917 & 908 \\
\hline $\mathrm{R}^{2}$ & 0.34 & 0.33 & 0.82 & 0.34 & 0.34 & 0.33 \\
\hline
\end{tabular}

Notes: $* * *$ significant at the $1 \%, * * 5 \%, * 10 \%$ level, respectively. T-statistics are shown in parentheses. All models estimated with heteroskedasticity robust standards errors. Models include period dummies (not reported), which are jointly significant in all cases at the $1 \%$ level.

change variable shows that it is actually the major democratic transitions that have been driving the results. Countries undergoing a major democratic transition receive a significant increase in per capita aid, while cases of positive regime change do not receive significantly more aid. This result shows that donors are more likely to support meaningful democratisations than smaller, potentially less visible changes.

In model 10, another lag for the two democratic change variables is added (and the lag of the level of democracy is also increased to account for this) in order to test how committed donors are to supporting new democracies in the longer run. The first lag of the major democratic change variable remains significant, but the second does not. The lags of the positive regime change variables are not significant at all. This result is troubling: donors give more aid to new democracies for a few years after their transition begins, but after that aid per capita again decreases. Therefore, it seems that donors in general do not commit themselves to providing longer-term support to new democracies, which are actually highly in need of it. This confirms previous results by Carothers (2002) and Levitsky - Way (2006).

An important question concerning the robustness of these results is how appropriate averaging the data for three-year periods is. Donors may react quickly to an event of democratisation and the three-year averages may hide such reactions. The specification used thus far may not be able to capture this. Model 11 therefore uses country-year data instead of the country three-year averages used so far. Using annual data instead of period averages does have a certain risk, as the high annual volatility of aid flows can cause distortions. However, annual data can allow to better test the timing of donor reactions and the duration of increased aid. Several lag structures have been experimented with and all show similar results; model 11 reports a structure with 5 lags. The first four lags of the major democratic change dummy are significant with meaningful coefficients. This confirms, but also refines the results of model 10: donors increase aid to major transitions the year right after the transition begins, and sustain higher aid 
volumes for three further years. Lags beyond the fifth are insignificant (these results are not reported, but available upon request), meaning that the support of donors trails off 5 years after a democratic transition began.

Model 12 tests whether there are differences in donor reactions to major democratic changes across regions, as the descriptive data in Table 2 implied. To do so, it includes four interaction variables between the major democratic change dummy and the four regional dummies used in models 1 and 2 . The non-interacted major democratic transition variable now thus measures the baseline, which is Asia. Although at varying levels, but all regional interactions and the baseline are significant, with the exception of Sub-Saharan Africa. Donors therefore seem to have rather consistently increased aid to democratising countries across regions, but have neglected Africa. This is an interesting finding that definitely warrants further study beyond the scope of this paper. Problems with governance in Africa were an important reason why donors began engaging in political conditionality and selective allocation in the 1990s, and democracy aid has clearly increased to the region during that decade (Dietrich - Wright 2013). This may not be reflected in total aid flows as donors may have responded by changing the composition of their aid (however, sectoral data on aid is only available from 1995, which makes it difficult to test this hypothesis). The literature on aid sanctions (Crawford 2001; Portela 2007) also provides evidence that donors have shown greater care about democracy in Africa by rather consistently cutting aid to African countries violating human rights and democratic principles.

Model 13 tests this issue of aid sanctions: do donors punish democratic reversals? To measure democratic reversals, a new dummy variable is introduced, also based on the Polity IV dataset and a similar logic as the democratic change variables. The dummy is equal to 1 if a decrease in a country's Polity score of 3 or more points begins in a given three-year period, and is also lagged. Again using the three-year averages set-up, the variable turns out to be significant, with a coefficient of a similar magnitude as the major democratic transition variable and with a negative sign. This result remains significant even after controlling for the intensity of civilian and interstate conflicts, which may have an impact both on democratic reversal and levels of foreign aid (model 14). Donors therefore not only reward major democratic change, but also punish democratic reversal.

\section{CONCLUSIONS}

This paper asked the question whether OECD DAC donors of foreign aid increase their assistance to developing countries where an event of democratisation happens. The data shows an affirmative answer, as in general donors do seem to react 
positively to democratic change. The experience is therefore in line with the rhetoric of donors, which has been emphasising that democratic countries deserve more aid, both from a moral and an aid-effectiveness perspective. This general conclusion can also help in giving credibility to the promises of increased aid that donors make, implicitly or explicitly, to autocratic or hybrid regime countries. More credible promises mean greater incentives for democratic change to happen.

The analysis, however, has also revealed some issues which nuance these conclusions. First, the greater the extent of democratisation, the higher the rewards. Donors tend to give more aid when countries introduce visible democratic changes and introduce some, not necessarily perfect, form of democracy. Smaller and less visible democratic changes are not followed by significantly higher aid per capita. Second, support to new democracies is not a long-term commitment. Increased aid flows trail off after a few years. Third, the paper has revealed regional variation in the responses of donors, with Sub-Saharan African democratisations being the ones which have not received "rewards", albeit the composition of aid to the region has most likely changed.

These conclusions are relevant from a normative policy standpoint, at least if one accepts the (debated) findings from the literature that aid is more effective in democratic environments. Donors need to develop strategies to remain engaged in new democracies in developing countries, which are usually in need of external financing to consolidate the new regime and build popular support. Further research is needed, however, to determine the types of aid which support this, and the types that do not. Also, as democracy is clearly the most fragile in Africa and there are still a large number of hybrid regimes in the region where sham democratic practices often serve to legitimise the ruling elite, an increased attention to promoting democracy in Africa may be needed. One element of such a strategy can be credible promises of increased aid in exchange for democratic reforms.

Of course, aid and democratic conditionality should not be viewed as the proven best solution to promote democracy. It may well be difficult to consolidate democracy, which is seen as externally imposed. Such conditionality therefore must not be too obtrusive, rather just provide soft incentives to support home-grown processes and domestic actors. As this paper highlighted, the key issue is the credibility of promises of increased aid by the donor community. The track record thus far seems promising, but clearly there is room for improvement. 


\section{REFERENCES}

Alesina, A. - Dollar, D. (2000): Who Gives Foreign Aid to Whom and Why? Journal of Economic Growth, 5(1): 33-63.

Alesina, A. - Weder, B. (2002): Do Corrupt Governments Receive Less Foreign Aid? American Economic Review, 92(4): 1126-1137.

Bandyopadhyay, S. - Wall, H. J. (2006): The Determinants of Aid in the post-Cold War Era. Federal Reserve Bank of St. Louis Working Paper, No. 2006-021B.

Bermeo, S. B. (2011): Foreign Aid and Regime Change: A Role for Donor Intent. World Development, 39(11): 2021-2031.

Berthélemy, J. C. (2006): Bilateral Donors' Interest vs. Recipients' Development Motives in Aid Allocation: Do All Donors Behave the Same? Review of Development Economics, 10(2): 179194.

Berthélemy, J. C. - Tichit, A. (2004): Bilateral Donors' Aid Allocation Decisions - A Three-Dimensional Panel Analysis. International Review of Economics and Finance, 13(3): 253-274.

Boone, P. (1996): Politics and the Effectiveness of Foreign Aid. European Economic Review, 40(2): 289-329.

Brautigam, D. - Knack, S. (2004): Foreign Aid, Institutions, and Governance in Sub-Saharan Africa. Economic Development and Cultural Change, 52(2): 255-285.

Burnside, C. - Dollar, D. (2000): Aid, Policies and Growth. American Economic Review, 90(4): 847-868.

Burnside, C. - Dollar, D. (2004): Aid, Policies and Growth: Revisiting the Evidence. World Bank Policy Research Working Paper, 3251.

Busse, M. - Gröning, S. (2009): Does Foreign Aid Improve Governance? Economic Letters, 104: 76-78

Carothers, T. (2002): The End of the Transition Paradigm. Journal of Democracy, 13(1): 5-21.

Claessens, S. - Cassimon, D. - Van Campenhout, B. (2009): Evidence on Changes in Aid Allocation Criteria. The World Bank Economic Review, 23(2): 185-208.

Collier, P. - Dollar, D. (2002): Aid Allocation and Poverty Reduction. European Economic Review, 46(3): 1475-1500.

Crawford, G. (2001): Foreign Aid and Political Reform: A Comparative Analysis of Democracy Assistance and Political Conditionality. Basingstoke: Palgrave.

Dietrich, S. - Wright, J. (2013): Foreign Aid and Democratic Development in Africa. In: Resnick, D. - van de Walle, N. (eds): Democratic Trajectories in Africa. Unravelling the Impact of Foreign Aid. Oxford: Oxford University Press, pp. 56-86.

Djankov, S. - Montalvo, J. - Reynal-Querol, M. (2008): The Curse of Aid. Journal of Economic Growth, 13(3): 169-94.

Dollar, D. - Levin, V. (2006): The Increasing Selectivity of Foreign Aid, 1984-2003. World Development, 34(12): 2034-2046.

Dovern, J. - Nunnenkamp, P. (2007): Aid and Growth Accelerations: An Alternative Approach to Assessing the Effectiveness of Aid. Kyklos, 60(3): 359-383.

Dutta, N. - Leeson, P. T. - Williamson, C. R. (2013): The Amplification Effect: Foreign Aid's Impact on Political Institutions. Kyklos, 66(2): 208-228.

Easterly, W. - Levine R. - Roodman, D. (2004): New Data, New Doubts: A Comment on Burnside and Dollar's Aid, Policies and Growth 2000. American Economic Review, 94(3): 774-780.

Hansen, H. - Tarp, F. (2001): Aid and Growth Regressions. Journal of Development Economics, 64(2): 547-570. 
Heckelman, J. C. (2010): Aid and Democratisation in the Transition Economies. Kyklos, 63(4): 558-579.

Hoebink, P. - Stokke, O. (eds) (2005): Perspectives on European Development Cooperation: Policy and Performance of Individual Donor Countries and the EU. London: Routledge.

Hoeffler, A. - Outram, V. (2011): Need, Merit, or Self-Interest - What Determines the Allocation of Aid? Review of Development Economics, 15(2): 237-250.

Isopi, A. - Mavrotas, G. (2006): Aid Allocation and Aid Effectiveness. An Empirical Analysis. UNU-WIDER Research Paper, 2006/07.

Janus, T. (2009): Aid and the Soft Budget Constraint. Review of Development Economics, 13(2): 264-275.

Kalyvitis, S. - Vlachaki, I. (2011): Democratic Aid and the Democratisation of Recipients. Contemporary Economic Policy, 28: 188-218.

Kalyvitis, S. - Vlachaki, I. (2012): When does More Aid Imply Less Democracy? An Empirical Examination. European Journal of Political Economy, 28(1): 132-146.

Kangoye, T. (2011): Does Foreign Aid Promote Democracy? Aid, Democracy, and Instability from Trade. UNU-WIDER Working Paper, 2011/64.

Kaufmann, D. - Kraay, A. - Mastruzzi, M. (2009): Governance Matters VIII. Aggregate and Individual Governance Indicators 1996-2008. World Bank Policy Research Working Paper, 4978.

Knack, S. (2001): Aid Dependence and the Quality of Governance: A Cross Country Empirical Test. Southern Economic Journal, 68(2): 310-329.

Knack, S. (2004): Does Foreign Aid Promote Democracy? International Studies Quarterly, 48: 251-256.

Knack, S. - Rahman, A. (2007): Donor Fragmentation and Bureaucratic Quality in Aid Recipients. Journal of Development Economics, 83(1): 176-197.

Kono, D. Y. - Montiola, G. R. (2009): Does Foreign Aid Support Autocrats, Democrats, or Both? The Journal of Politics, 70(2): 704-718.

Kosack, S. (2003): Effective Aid: How Democracy Allows Development Aid to Improve the Quality of Life. World Development, 31(1): 1-22.

Lancaster, C. (2006): Foreign Aid: Diplomacy, Development, Domestic Politics. Chicago: University of Chicago Press.

Levitsky, S. - Way, L. A. (2006): Linkage versus Leverage. Rethinking the International Dimension of Regime Change. Comparative Politics, 38(4): 379-400.

Maizels, A. - Nissanke, M. K. (1984): Motivations for Aid to Developing Countries. World Development, 12(9): 879-900.

Marshall, M. G. (2012): Major Episodes of Political Violence 1946-2012. Vienna, VA: Center for Systemic Peace.

Marshall, M. G. - Jaggers, K. - Gurr, T. R. (2011): Polity IV Project. Political Regime Characteristics and Transitions, 1800-2010. Vienna, VA: Center for Systemic Peace.

McGillivray, M. (2003): Modelling Aid Allocation: Issues, Approaches and Results. UNU-WIDER Research Paper, No. 2003/49.

McKinley, R. D. - Little, R. (1977): A Foreign Policy Model of U.S. Bilateral Aid Allocation. World Politics, 30(1): 58-86.

McKinley, R. D. - Little, R. (1979): The U.S. Aid Relationship: A Test of the Recipient Need and the Donor Interest Models. Political Studies, 27(2): 236-250.

Moss, T. - Pettersson, G. - Van de Walle, N. (2006): An Aid-Institutions Paradox? A Review Essay on Aid Dependency and State Building in Sub-Saharan Africa. Center for Global Development Working Paper, 74. 
Neumayer, E. (2003a): Do Human Rights Matter in Bilateral Aid Allocation? A Quantitative Analysis of 21 Donor Countries. Social Science Quarterly, 84(3): 650-666.

Neumayer, E. (2003b): The Determinants of Aid Allocation by Regional Multilateral Development Banks and United Nations Agencies. International Studies Quarterly, 47(1): 101-122.

Neumayer, E. (2003c): Is Respect for Human Rights Rewarded? An Analysis of Total Bilateral and Multilateral Aid Flows. Human Rights Quarterly, 25(2): 510-527.

OECD (2012): International Development Statistics (IDS) online databases on aid and other resource flows (http://www.oecd.org/dac/aidstatistics/, accessed 10 June 2012).

Pacquement, F. (2010): How Development Assistance from France and the United Kingdom has Evolved: Fifty Years on from Decolonisation. Revue internationale de politique de développement, 1: 51-75 (http://poldev.revues.org/137, accessed 8 September 2012).

Portela, C. (2007): Aid Suspensions as Coercive Tools? The European Union's Experience in the African-Caribbean-Pacific (ACP) Context. Review of European and Russian Affairs, 3(2): 38 53.

Rodriguez, F. - Rodrik, D. (2001): Trade Policy and Economic Growth: A Skeptic's Guide to the Cross-National Evidence. In: Bernanke, B. S. - Rogoff, K. (eds): NBER Macroeconomics Annual 2000, Volume 15. Boston: MIT Press.

Schraeder, P. J. - Hook, S. W. - Taylor, B. (1998): Clarifying the Foreign Aid Puzzle: A Comparison of American, Japanese, French, and Swedish Aid Flows. World Politics, 50(2): 294-323.

Svensson, J. (1999): Aid, Growth and Democracy. Economics and Politics, 11(3): 275-297.

Svensson, J. (2000): Foreign Aid and Rent-Seeking. Journal of International Economics, 51(2): 437-461.

Tarrósy, I. (2012): Two Giants on the Same Soil: A Closer Look at Afro-Asian Relations via Comparing Chinese and Japanese Involvement in Tanzania. Portuguese Journal of International Affairs, 6 (Spring/Summer): 52-63.

Trumbull, W. N. - Wall, H. J. (1994): Estimating Aid-Allocation Criteria with Panel Data. The Economic Journal, 104(425): 876-882.

Wright, J. (2009): How Foreign Aid can Foster Democratisation in Authoritarian Regimes. American Journal of Political Science, 53(3): 552-571.

Younas, J. (2008): Motivation for Bilateral Aid Allocation: Altruism or Trade Benefits. European Journal of Political Economy, 24(3): 661-674. 